\title{
PENGEMBANGAN PARIWISATA BERBASIS MASYARAKAT DI KAWASAN SEBERANG KOTA JAMBI (SEKOJA)
}

\author{
Yustisia Kristiana ${ }^{1)}$, Rosdiana Pakpahan ${ }^{2)}$, Stephanie T. Mulyono ${ }^{3)}$ \\ 1) Universitas Pelita Harapan, Tangerang \\ 2) Universitas Pelita Harapan, Tangerang \\ 3) Universitas Pelita Harapan, Tangerang
}

yustisia.kristiana@uph.edu, rosdiana.pakpahan@uph.edu, stephanie.mulyono@uph.edu

\begin{abstract}
Abstrak
Provinsi Jambi mempunyai potensi wisata yang cukup beragam, berupa keanekaragaman hayati yang meliputi flora dan fauna, kekayaan alam, serta peninggalan sejarah. Kota Jambi sebagai ibukota Provinsi Jambi memiliki banyak sekali daya tarik wisata yang berpotensi dan menarik untuk dikunjung. Potensi pariwisata yang dimiliki Kota Jambi begitu menarik untuk dikunjungi salah satunya adalah Seberang Kota Jambi atau yang di kenal dengan sebutan Sekoja. Seberang Kota Jambi merupakan kawasan Kota Jambi yang terletak di tepi utara Sungai Batanghari. Sekoja menyajikan begitu banyak hal yang menarik dan berbeda, mulai dari keindahan panorama, keunikan adat budaya dan kearifan lokal masyarakat, hingga tempat bersejarah. Permasalahan yang dihadapi oleh kelompok mitra komunitas masyarakat Sekoja (Seberang Kota Jambi) adalah kurangnya pengetahuan masyarakat tentang pengelolaan pariwisata berbasis masyarakat, kurangnya pengetahuan masyarakat tentang pengaturan rute perjalanan wisata dan kurangnya infomasi bagi wisatawan tentang atraksi, akomodasi dan aktivitas wisata. Tujuan dari kegiatan ini adalah untuk meningkatkan pemahaman masyarakat tentang pengelolaan pariwisata berbasis masyarakat, terwujudnya rute perjalanan wisata dan terciptanya brosur wisata. Metode yang dilakukan yaitu sosialisasi program, melakukan pelatihan dan evaluasi. Hasil yang dicapai dari kegiatan ini adalah peningkatan pemahaman masyarakat tentang pengelolaan pariwisata berbasis masyarakat, terwujud rute perjalanan wisata dan tercipta brosur wisata.
\end{abstract}

Kata Kunci: pariwisata berbasis masyarakat, rute perjalanan wisata, brosur wisata, Sekoja 


\section{PENDAHULUAN}

Provinsi Jambi merupakan provinsi dengan komponen wisata khas di Pulau Sumatera. Provinsi Jambi mempunyai potensi wisata yang cukup beragam, berupa keanekaragaman hayati yang meliputi flora dan fauna, kekayaan alam yang melimpah, peninggalan sejarah yang tersebar di beberapa kabupaten serta adat istiadat dan kebudayaan penduduknya. Modal tersebut merupakan aset penting bagi perkembangan industri pariwisata.

Daya tarik wisata alam di Provinsi Jambi antara lain Taman Nasional Kerinci Sebelat (TNKS), Danau Kerinci, Danau Gunung Tujuh, Air Terjun Telun Berasap yang semuanya terletak di Kerinci, Bukit Khayangan di Sungai Penuh, Air Terjun Sungai Piul di Merangin, Danau Sigombak di Tebo, Taman Nasional Berbak di Tanjung Jabung Timur dan lain-lain. Wisata peninggalan sejarah adalah Kawasan Candi Muaro Jambi di Kabupaten Muaro Jambi. Terdapat juga istana dan Makam Sultan Thaha Syaifuddin, merupakan pahlawan nasional berasal dari Jambi dan sultan yang terakhir keturunan Jambi. Tarian tradisional dan upacara adat merupakan daya tarik tersendiri seperti Tari Sekapur Sirih yang diperagakan pada saat menerima tamu kehormatan serta Tarian Ranguh Selampit Delapan, Tarian Tauh, Pencak Silat, Joget Melayu, Tari Asyik dan Tari Tolak Bala yang merupakan seni tradisional dan diperagakan dengan memakai pakaian tradisional berwarna warni.

Daya tarik wisata yang dimiliki oleh Provinsi Jambi berada di seluruh kabupaten dan kota. Menurut Ismayanti (2010), daya tarik wisata adalah usaha pengelolaan daya tarik wisata alam, budaya dan buatan. Wisatawan yang berkunjung ke Provinsi Jambi mengalami kenaikan sebesar $17 \%$ pada tahun 2018. Jumlahnya yakni dari kota Jambi sebanyak 700.000 wisatawan, Kerinci dan Sungai Penuh 250.000 wisatawan, Sarolangun 25.000 wisatawan, Muaro Jambi 240.000 wisatawan, Merangin 400.000 wisatawan, Bungo 61.000 wisatawan, Tebo 6.302 wisatawan, Tanjung Jabung Timur 2000 wisatawan, Tanjung Jabung Barat 6.000 wisatawan, dan Batanghari 7.000 wisatawan.

Kota Jambi sebagai ibukota Provinsi Jambi memiliki keragaman daya tarik wisata, diantaranya kawasan Seberang Kota Jambi atau Sekoja. Seberang Kota Jambi adalah kawasan Kota Jambi yang terletak di sebelah utara dari Sungai Batanghari. Sekoja menawarkan keindahan panorama Sungai Batanghari, keunikan budaya, tempat-tempat bersejarah dan kearifan lokal dari masyarakat. Wisatawan juga dapat menikmati keindahan panorama Sungai Batanghari dengan menggunakan perahu penyeberangan, yang oleh masyarakat disebut ketek.

Masyarakat yang tinggal di seberang sungai Kota Jambi sangat lekat dengan perkembangan agama Islam. Di kawasan tersebut terdapat dua kecamatan yakni Kecamatan Danau Teluk dan Kecamatan Pelayangan serta 11 kelurahan. Jejak perkembangan agama Islam dapat terlihat dengan berdirinya pesantren di antaranya Pesantren As'ad, Pesantren Nurul Iman, Pesantren Sa'adatuddaren, Pondok Pesantren Al-Jauharen dan masih banyak lagi. Terdapat juga Masjid Ikhsaniyyah yang memiliki nilai sejarah. Salah satu cagar budaya yang menjadi daya tarik adalah Rumah Batu Olak Kemang. Rumah Batu Olak Kemang merupakan peninggalan Sayyid Idrus bin Hasan Al Jufri atau Pangeran Wirokusumo, beliau adalah penyiar Islam pertama yang masuk ke Jambi. Keunikan lainnya di kawasan Seberang Kota Jambi adalah arsitektur rumah yang menampilkan perpaduan dari budaya Melayu, Tionghoa dan Arab. Keberadaan masyarakat Jambi di seberang kota tidak dapat dilepaskan dari proses dan perjalanan sejarah Kota Jambi. Bahkan salah satu murid yang pernah belajar di pesantren Nurul Imam yaitu Drs. H. Hasan Basri Agus adalah Gubernur Jambi periode 2010-2015.

Undang-Undang No. 10 Tahun 2009 tentang Kepariwisataan menyatakan bahwa pariwisata merupakan kegiatan wisata yang ditunjang dengan berbagai fasilitas wisata serta layanan. Pengembangan pariwisata di Kota Jambi, khususnya di kawasan Seberang Kota Jambi dilakukan dengan pendekatan pengembangan pariwisata berbasis masyarakat. Pariwisata berbasis masyarakat dikembangkan dengan mengedapankan prinsip kesepadanan dan kesesuaian kepentingan para pemangku kepentingan pariwisata. Pariwisata berbasis masyarakat merupakan bentuk pariwisata yang menitikberatkan keberlanjutan di bidang lingkungan, sosial, dan budaya. Pengembangan

$$
\text { Ekonomi, Sosial, dan Budaya }
$$

1048 
pariwisata oleh masyarakat dilakukan dengan tujuan untuk meningkatkan kesadaran wisatawan dan mempelajari cara hidup masyarakat lokal (Suansri, 2003). Pengembangan pariwisata berbasis masyarakat bertujuan untuk mengoptimalkan pemberdayaan masyarakat, meningkatkan peran serta masyarakat dalam pengembangan pariwisata sehingga dapat memperoleh manfaat di bidang ekonomi maupun sosial budaya dan memberikan peluang yang sama bagi seluruh masyarakat.

Pendekatan yang diterapkan untuk mengembangkan pariwisata berbasis masyarakat adalah bentuk pendekatan partisipatif. Pendekatan ini dipilih untuk mendukung terbentuknya kemitraan di antara pemangku kepentingan pariwisata. Melalui pendekatan ini maka masyarakat lokal harus mengetahui potensi yang dimiliki sehingga mempunyai rasa memiliki terhadap beragam sumber daya sebagai aset pembangunan pariwisata (Dengnoy, 2003).

Komponen pariwisata menjadi empat komponen utama, yaitu attraction, amenities, accessibility dan ancillary services (Fletcher et al., 2017). Attraction adalah daya tarik wisata pada sebuah destinasi wisata seperti keindahan alam, budaya dan aktivitas masyarakat, serta atraksi buatan seperti sarana permainan dan hiburan. Amenities adalah ketersediaan sarana penunjang kebutuhan pengunjung selama melakukan kegiatan wisata, seperti tersedianya layanan makanan dan minuman serta akomodasi. Accessibility dapat berupa ketersediaan sarana transportasi menuju destinasi wisata dan selama wisatawan berada di destinasi wisata. Ancillary service adalah layanan lain-lain yang menunjang kegiatan pariwisata, dapat berupa sarana tambahan seperti pusat infomasi pariwisata, money changer dan lain sebagainya.

Mitra dalam kegiatan ini adalah komunitas masyarakat Sekoja (Seberang Kota Jambi) yang terdiri dari komunitas GenPI (Generasi Pesona Indonesia) Provinsi Jambi, kelompok pengrajin batik Jambi dan masyarakat Sekoja. Untuk dapat mewujudkan pariwisata di Kota Jambi dibutuhkan kesiapan masyarakat, terkait pengelolaan pariwisata. Pemahaman masyarakat tentang pariwisata dan pengelolaannya masih sangat kurang. Permasalahan prioritas yang dihadapi oleh mitra adalah 1) kurangnya pengetahuan masyarakat tentang pengelolaan pariwisata berbasis masyarakat, sosialisasi dan penyuluhan tentang pengembangan pariwisata yang berbasis masyarakat perlu dilakukan oleh tenaga ahli pariwisata; 2) kurangnya pengetahuan masyarakat tentang pengaturan rute perjalanan wisata, masyarakat belum mengetahui pengaturan rute perjalanan wisata, pelatihan pengelolaan atraksi wisata dilakukan oleh tenaga ahli di bidang perjalanan wisata; 3) kurangnya infomasi bagi wisatawan tentang atraksi, akomodasi dan aktivitas wisata, tidak ada informasi terkait pariwisata, sehingga perlu diberikan pelatihan pembuatan brosur yang menarik, pelatihan penyusunan brosur dilakukan oleh tenaga ahli di bidang promosi pariwisata.

\section{METODE}

Tahap awal pelaksanaan ini adalah sosialisasi program. Sosialisasi dilakukan dengan melakukan pertemuan awal dengan Pemerintah Daerah dalam hal ini diwakili oleh Dinas Pariwisata dan Kebudayaan Provinsi Jambi dan perwakilan dari masyarakat Seberang Kota Jambi. Setelah pertemuan dilanjutkan dengan identifikasi potensi wisata yang dimiliki. Setelah tim menemukan potensi-potensi yang dapat dikembangkan seperti potensi alam, potensi ekonomi, sosial dan sumber daya manusia yang mendukung untuk mengembangkan program pariwisata berbasis masyarakat di kawasan Seberang Kota Jambi.

Tahap kedua adalah mengadakan penyuluhan dan pelatihan untuk meningkatkan kompetensi sumber daya manusia dalam pengembangan pariwisata. Penyuluhan dan pelatihan dilaksanakan dengan topik terkait pengelolaan pariwisata berbasis masyarakat, pengaturan rute perjalanan wisata dan penyusunan brosur wisata. Partisipasi peserta pelatihan sangat baik dan mampu memahami materi yang disampaikan. Untuk meningkatkan antusias peserta, dilakukan kegiatan kunjungan ke daya tarik wisata yang terdapat di Seberang Kota Jambi. 


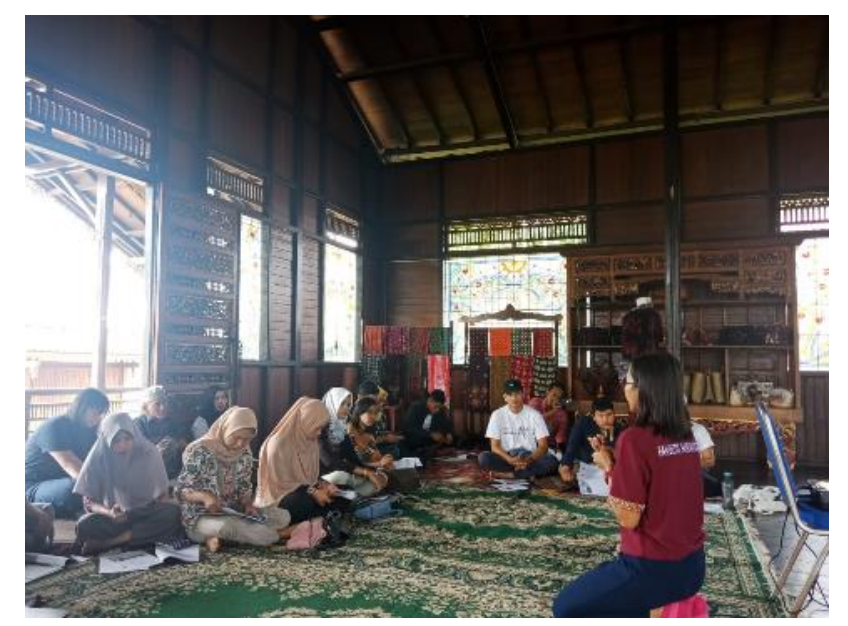

Gambar 1. Pemberian Materi

Tahap terakhir merupakan tahap evaluasi. Tahap evaluasi, tahap ini merupakan tahap dimana program dievaluasi secara menyeluruh untuk meningkatkan mutu program dalam pengembangan program selanjutnya. Salah satu fungsi evaluasi adalah memperbaiki atau melakukan penyempurnaan kembali (Sudijono, 2009). Untuk mengetahui pemahaman peserta terhadap materi yang diberikan, dilakukan evaluasi dengan cara memberikan pertanyaan-pertanyaan tentang materi. Selain itu menanyakan kepada peserta tentang kesan dan masukan mengenai pelaksanaan kegiatan.

\section{HASIL DAN PEMBAHASAN}

Pelaksaanan diawali dengan registrasi, memberikan materi kepada peserta kegiatan, penyampaian materi, kunjungan lapangan dan sesi tanya jawab. Pelaksanaan kegiatan yang telah diselenggarakan adalah pengembangan pariwisata berbasis masyarakat di kawasan Seberang Kota Jambi (Sekoja) dengan waktu pelaksanaan pada hari Selasa, 12 Maret 2019.

Kegiatan dibuka oleh Ibu Damora, S.E., M.M. selaku Kabid Pariwisata Dinas Pariwisata dan Kebudayaan Provinsi Jambi. Peserta kegiatan di
Sekoja ini sejumlah 20 orang, yaitu anggota GenPI Provinsi Jambi, pengrajin batik Jambi dan masyarakat Sekoja. Kegiatan diadakan dalam tiga sesi dalam bentuk penyampaian materi dan kunjungan lapangan ke beberapa daya tarik wisata di kawasan Sekoja. Kegiatan dilakukan di sebuah sanggar batik yang juga menjual batik khas Jambi hasil kreasi masyarakat Sekoja. Susunan acara kegiatan pengabdian kepada masyarakat adalah sebagai berikut:

Tabel 1. Susunan Acara

\begin{tabular}{|c|c|}
\hline Waktu & Kegiatan \\
\hline 09.00-09.30 & $\begin{array}{l}\text { Registrasi } \\
\text { Pembukaan oleh Ibu Damora, S.E., M.M. } \\
\text { (Kabid Pariwisata Dinas Pariwisata dan } \\
\text { Kebudayaan Provinsi Jambi) }\end{array}$ \\
\hline $09.30-10.30$ & $\begin{array}{l}\text { Sesi } 1 \\
\text { Pelatihan Pengelolaan Pariwisata yang } \\
\text { Berbasis Masyarakat } \\
\text { Narasumber: Yustisia Kristiana, S.ST., } \\
\text { M.M. }\end{array}$ \\
\hline $1030-12.00$ & $\begin{array}{l}\text { Sesi } 2 \\
\text { Pelatihan Tentang Pengaturan Rute } \\
\text { Perjalanan Wisata dan Kunjungan } \\
\text { Lapangan } \\
\text { Narasumber: Rosdiana Pakpahan, S.Par., } \\
\text { M.Sc. }\end{array}$ \\
\hline $12.00-13.00$ & ISHOMA \\
\hline $13.00-14.00$ & $\begin{array}{l}\text { Sesi } 3 \\
\text { Pelatihan Pembuatan Brosur Wisata } \\
\text { Narasumber: Stephanie T. Mulyono, } \\
\text { S.ST., M.Par. }\end{array}$ \\
\hline $14.00-15.00$ & Penutupan \\
\hline $15.00-15.30$ & Foto bersama \\
\hline
\end{tabular}

Pelaksaanan diawali dengan registrasi, memberikan materi kepada peserta kegiatan, penyampaian materi, kunjungan lapangan dan sesi tanya jawab. Pelaksanaan kegiatan yang telah diselenggarakan adalah pengembangan pariwisata berbasis masyarakat di kawasan Seberang Kota Jambi (Sekoja) dengan waktu pelaksanaan pada hari Selasa, 12 Maret 2019.

Kegiatan dibuka oleh Ibu Damora, S.E., M.M. selaku Kabid Pariwisata Dinas Pariwisata dan Kebudayaan Provinsi Jambi. Peserta kegiatan di Sekoja ini sejumlah 20 orang, yaitu anggota GenPI Provinsi Jambi, pengrajin batik Jambi dan

Ekonomi, Sosial, dan Budaya 
masyarakat Sekoja. Kegiatan diadakan dalam tiga sesi dalam bentuk penyampaian materi dan kunjungan lapangan ke beberapa daya tarik wisata di kawasan Sekoja. Kegiatan dilakukan di sebuah sanggar batik yang juga menjual batik khas Jambi hasil kreasi masyarakat Sekoja.

Tim memberikan pengetahuan tentang pengelolaan pariwisata yang berbasis masyarakat, pengaturan rute perjalanan wisata dan pembuatan brosur wisata. Materi pariwisata berbasis masyarakat diberikan kepada peserta agar meningkatkan kesadaran masyarakat tentang konsep pariwisata berbasis masyarakat. Pariwisata berbasis masyarakat menitikberatkan peran aktif komunitas. Pariwisata berbasis masyarakat diyakini mampu menciptakan kesempatan kerja bagi masyarakat dan meningkatkan kesejahteraan. Model pengembangan pariwisata berbasis masyarakat dikembangkan dengan memperhatikan kebutuhan masyarakat dan tetap menjaga nilai-nilai yang terdapat dalam masyarakat. Pariwisata berbasis masyarakat memberikan peluang bagi masyarakat untuk terlibat sepenuhnya dalam membangun pariwisata (Kristiana, 2019). Supaya pelaksanaan pariwisata berbasis masyarakat dapat berhasil dengan baik, ada elemen-elemen pariwisata berbasis masyarakat yang harus diperhatikan, yakni sumber daya alam dan budaya, organisasi-organisasi masyarakat, manajemen dan pembelajaran. Dalam pengembangan pariwisata berbasis masyarakat, peran masyarakat sama pentingnya sebagai salah satu pemangku kepentingan, bersama dengan pemerintah dan industri swasta (Sunaryo, 2013).

Materi yang kedua adalah tentang pengaturan rute perjalanan. Dalam menyusun rute perjalanan perlu mempertimbangkan pola perjalanan. Bentuk pola perjalanan menurut Lau dan McKercher (2006) dapat dibagi menjadi 1) single point yaitu pola perjalanan yang menuju hanya satu destinasi dan kembali lagi ke destinasi awal dengan menggunakan rute yang sama, 2) base site yaitu pola perjalanan wisatawan yang dimulai dengan perjalanan dari daerah asal dan menuju ke daerah tujuan utama, lalu dilanjutkan melakukan perjalanan ke destinasi sekunder dalam wilayah tertentu, 3) stopover yaitu pola perjalanan wisatawan yang menuju satu titik destinasi utama dan dalam perjalanannya mengunjungi titik destinasi lain (sekunder), 4) chaining loop yaitu pola perjalanan dengan tipe memutar seperti cincin yang menghubungkan dua atau lebih titik destinasi dan tidak terjadi pengulangan rute, 5) destination region loop yaitu pola perjalanan dimana setelah wisatawan menyelesaikan perjalanan secara berkeliling (pola lingkaran) akan kembali ke destinasi asal melalui rute yang paling singkat antara tujuan utama dan destinasi asal pada saat keberangkatan. Ini merupakan kombinasi dari pola single point dan chaining loop dan 6) complex neighborhood merupakan kombinasi dua atau lebih pola perjalanan. Pola perjalanan sangat diperlukan dalam menyusun paket wisata. Paket wisata diartikan sebagai perjalanan wisata dengan mengunjungi satu atau beberapa destinasi yang disusun dari beberapa komponen perjalanan wisata dan ditawarkan sebagai harga tunggal (Nuriata 2014). Untuk melengkapi pengetahuan tentang rute perjalanan, setelah penyampaian materi peserta melakukan kunjungan lapangan ke beberapa daya tarik wisata di kawasan Seberang Kota Jambi yaitu Taman Sanggar Batik, Balai Kerajinan Rakyat Selaras Pinang Masaka, Menara Gentala Arasy, Museum Gentala Arasy dan Setya Tree House.

Materi yang terakhir adalah tentang pembuatan brosur wisata. Brosur wisata merupakan panduan wisatawan untuk memudahkan dalam berwisata. Brosur merupakan salah satu media promosi dan termasuk teknik advertising. Advertising merupakan penyampaian pesan persuasif untuk menginformasikan dan membujuk target pasar tertentu tentang produk maupun layanan (Morrison, 2010). Dalam membuat brosur wisata perlu dipikirkan apa yang ingin disampaikan dalam brosur wisata menyangkut daya tarik wisata yang akan diinformasikan kepada wisatawan. Peserta diajak untuk membuat brosur wisata yang menarik yang mampu menginformasikan daya tarik wisata yang dimiliki sehingga mendorong wisatawan untuk berkunjung ke kawasan Seberang Kota Jambi. Brosur wisata ini dapat dicetak atau diunggah dalam media sosial yang dikelola oleh GenPI Provinsi Jambi. 


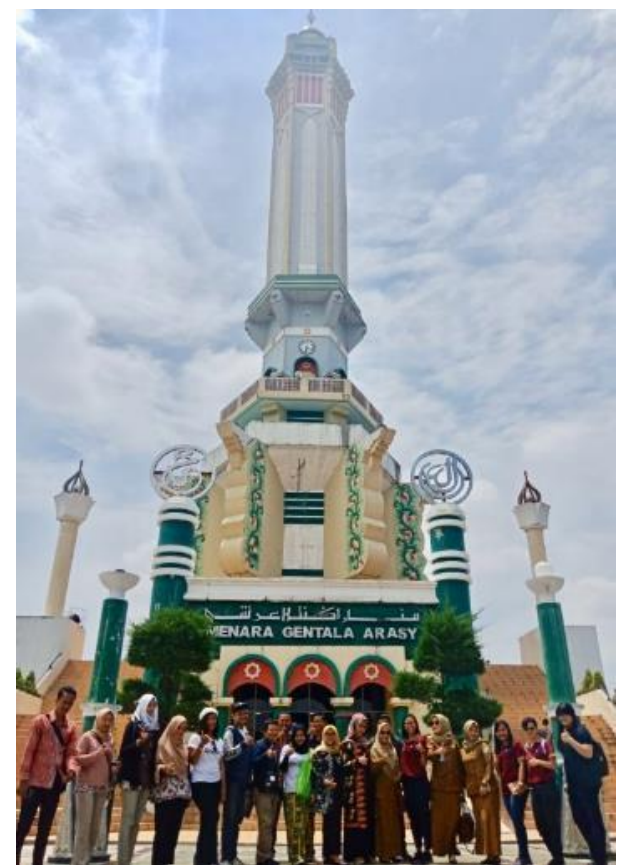

Gambar 2. Kunjungan Lapangan

Pada acara penutupan, peserta menyampaikan kesan dan masukan tentang pelaksanaan kegiatan kemudian ditutup secara resmi oleh Ibu Damora, S.E., M.M. Setelah ditutup secara resmi, dilanjutkan foto bersama.

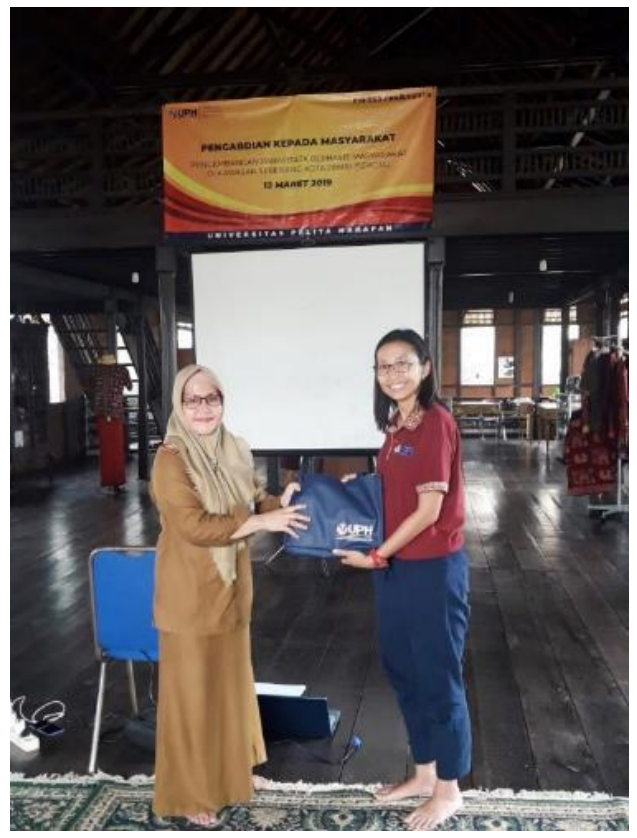

\section{Gambar 3. Acara Penutupan}

Kegiatan pengembangan pariwisata berbasis masyarakat di kawasan Seberang Kota Jambi (Sekoja) telah berjalan dengan lancar. Untuk mengevaluasi kegiatan yang dilakukan, tim memberikan pertanyaan kepada peserta terkait tentang materi pelatihan. Hasilnya menunjukkan bahwa peserta mampu menjawab pertanyaanpertanyaan dengan baik, hal ini menunjukkan bahwa peserta mampu memahami materi yang diberikan.

Melalui kegiatan ini terwujud pemahaman masyarakat tentang pengelolaan pariwisata berbasis masyarakat. Selain itu disusun alternatif rute perjalanan wisata di kawasan Seberang Kota Jambi (Sekoja) yaitu 1) Taman Sanggar Batik - Balai Kerajinan Rakyat Selaras Pinang Masak - Menara dan Museum Gentala Arasy - Setya Tree House; 2) Rumah Batu Olak Kemang - Makam Pangeran Wirokusumo - Masjid Ikhsaniyyah - Pesantren Nurul Iman dan 3) Rumah Batu Olak Kemang Makam Pangeran Wirokusumo - Taman Sanggar Batik - Balai Kerajinan Rakyat Selaras Pinang Masak - Menara dan Museum Gentala Arasy - Setya Tree House.
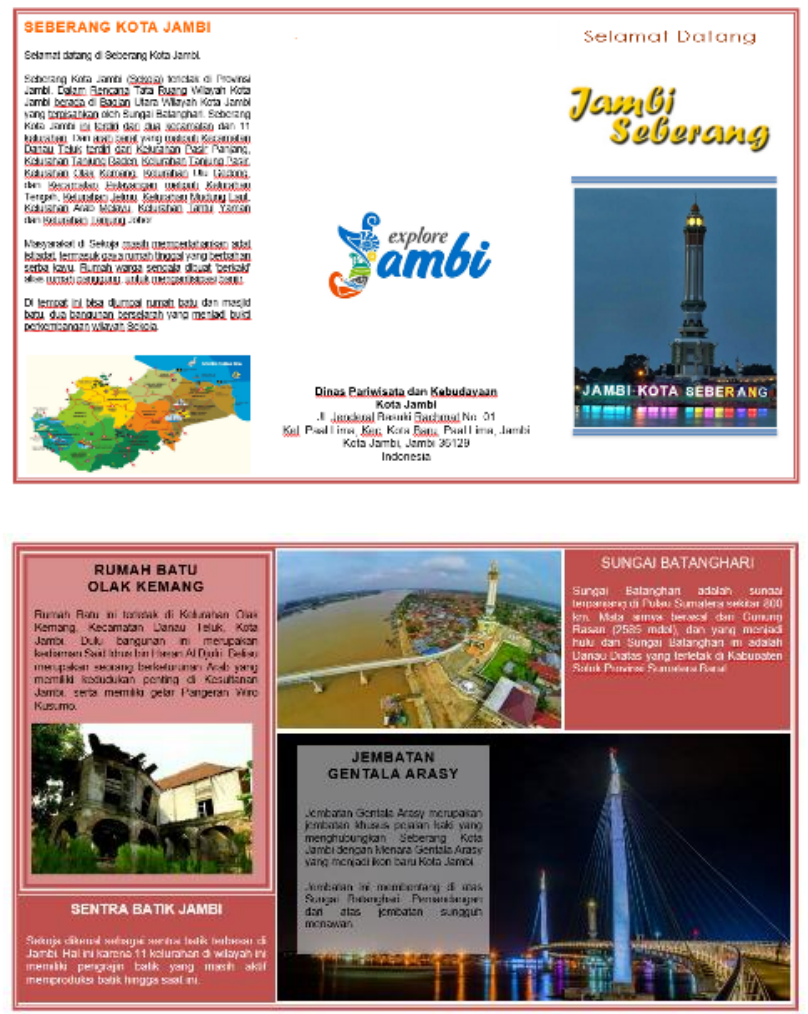

Ekonomi, Sosial, dan Budaya 


\section{Gambar 4. Contoh Brosur Wisata}

Dalam kegiatan ini masyarakat memiliki pengetahuan dalam untuk menyusun brosur wisata yang menarik yang memuat informasi tentang atraksi, akomodasi dan aktivitas wisata.

\section{SIMPULAN}

Kegiatan pengabdian kepada masyarakat pengembangan pariwisata berbasis masyarakat dilakukan dengan tahapan sosialisasi program, pelaksanaan dan evaluasi. Kegiatan dilaksanakan di Kawasan Seberang Kota Jambi, Provinsi Jambi dan diikuti oleh 20 peserta. Kegiatan yang dilakukan dapat dirasakan manfaatnya bagi mitra. Hasil evaluasi kegiatan menunjukkan bahwa peserta mampu memahami materi yang diberikan. Implikasi kegiatan ini bagi masyarakat antara lain 1) meningkatkan kesadaran masyarakat tentang pariwisata berbasis masyarakat, 2) meningkatkan partisipasi masyarajat dan 3) meningkatkan perekonomian masyarakat melalui kegiatan pariwisata. Kegiatan ini perlu pendampingan pendampingan khususnya dalam penyusunan paket wisata religi, yang mampu mengintegrasikan antara potensi wisata religi yang dimiliki oleh Seberang Kota Jambi.

\section{UCAPAN TERIMA KASIH}

Kegiatan pengabdian kepada masyarakat di Seberang Kota Jambi ini dapat terlaksana dengan baik berkat adanya dukungan dari semua pihak. Ucapan terima kasih disampaikan kepada Dekan Fakultas Pariwisata Universitas Pelita Harapan, LPPM Universitas Pelita Harapan, Dinas Pariwisata dan Kebudayaan Provinsi Jambi, GenPI Provinsi Jambi serta masyarakat Seberang Kota Jambi.

\section{REFERENSI}

Dengnoy, J. (2003). Community based tourism: the sustainability challenge (A case study of responsible ecological social tours project). Thailand: REST Project.
Fletcher, J., Fyall, A., Gilbert, D. dan Wanhill, S. (2017). Tourism: Principles and Practice. 6th ed. Harlow: Pearson Education.

Kristiana, Y. (2019). Buku Ajar Studi Ekowisata. Yogyakarta: Penerbit Deepublish.

Ismayanti (2010). Pengantar Pariwisata. Jakarta: PT Gramedia Widisarana Indonesia.

Lau, G. dan McKercher, B. (2006). Understanding Tourist Movement Patterns in A Destination: A GIS Approach. Hongkong. Retrieved from

http://www.scribd.com/doc/20752930/Understandin g-Tourist-Movement-Patterns

Morrison, Alastair M. (2010). Hospitality \& Travel Marketing, $4^{\text {th }}$ Edition. USA: Delmar.

Nuriata (2014). Paket Wisata: Penyusunan Produk dan Penghitungan Harga. Bandung: Alfabeta

Republik Indonesia. 2009. Undang-Undang Republik Indonesia Nomor 10 Tahun 2009 Tentang Kepariwisataan. Indonesia.

Suansri, Potjana (2003). Community Based Tourism Handbook. Thailand: REST Project.

Sudijono, A. (2009). Pengantar Evaluasi Pendidikan. Jakarta: PT. Raja Grafindo Persada.

Sunaryo, Bambang (2013). Kebijakan Pembangunan Destinasi Pariwisata Konsep dan Aplikasinya di Indonesia. Yogyakarta: Gava Media. 